\title{
In Bulgaria
}

\section{Eleventh Festival of Red Cross and Health Films}

Every two years since 1965, the city of Varna in Bulgaria has played host to the International Festival of Red Cross and Health Films. The eleventh festival was held this year from 7 to 15 June. For the final competition the jury selected 194 films from 58 countries, made by 27 National Red Cross and Red Crescent Societies and seven international organizations.

The festival, organized by the Bulgarian Red Cross, under the patronage of the League, the ICRC and the WHO, was attended by almost 500 guests including many high-ranking members of National Societies and heads of their information services. Mr. Enrique de la Mata Gorostizaga, President of the League, and Dr. Ahmed Abu-Goora, President of the Standing Commission of the International Red Cross, were at the opening ceremony. Mr. Maurice Aubert, Vice-President of the ICRC, accompanied by $\mathrm{Mr}$. Alain Modoux, head of the ICRC Information Department, represented the International Committee at the closing ceremony.

There was a large public attendance, with over 100,000 people coming to the various showings.

In accordance with now established practice, the films in the competition were divided into four categories: A. Red Cross films; B. short to medium-length films on health; C. feature films; D. television programmes and films.

The Grand Prix in the category of Red Cross films, "The Golden Ship", from the President of the Bulgarian Red Cross, went to "A message from Aaland", which is a co-production by the League, the ICRC and the Finnish and Swedish Red Cross Societies. The League's Grand Prix was awarded to the American Red Cross for its "Light the Darkness", which consists of extracts of recent ICRC and League films. The main prize for feature films 
went to "Saints Innocents", by Mario Camus (Spain), and the main prize in the television section to a Canadian film called "The Last Right". Numerous other prizes were awarded.

The Varna film festival provides the National Societies, the League and the ICRC with an excellent opportunity to have a look at new audio-visual productions, and to establish or keep up personal and professional friendships. As the President of the Bulgarian Red Cross, Mr. Kiril Ignatov, said at the opening ceremony, "This international festival serves the humanitarian cause of protecting health and contributing to peace and progress in the world."

\title{
Thirtieth award of the Florence Nightingale Medal
}

\author{
Geneva, 12 May 1985
}

Circular No. 535

\section{To the Central committees of National Red Cross and Red Crescent Societies}

\section{LADIES AND GENTLEMEN,}

In its Circular No. 530 of 24 August 1984, the International Committee of the Red Cross had invited the Central Committees of National Societies to send in the names of nurses and voluntary aids who are active members or regular helpers of a National Society or of an affiliated medical or nursing institution, whom they judged qualified to receive the Florence Nightingale Medal.

The object of this Medal is to honour nurses and voluntary aids who have distinguished themselves in time of peace or war, by their exceptional courage and devotion to wounded, sick or disabled persons or those whose health is threatened.

The International Committee, after a careful study of the candidatures submitted by National Societies, has the pleasure of 